\begin{tabular}{|c|c|c|c|c|}
\hline \multicolumn{5}{|c|}{ НАУЧНО-ТЕХНИЧЕСКИЙ ВЕСТНИК ИНФОРМАЦИОННЫХ ТЕХНОЛОГИЙ, МЕХАНИКИ И ОПТИКИ } \\
\hline 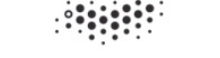 & $\begin{array}{l}\text { ноябрь-декабрь } 2015 \\
\text { SCIENTIFIC AND TECF }\end{array}$ & $\begin{array}{l}\text { ToM } 15 \text { № } 6 \\
\text { L J JSURN 2226-1494 }\end{array}$ & $\begin{array}{l}\text { http://ntv.ifmo.ru/ } \\
\text { IECHANICS AND OPTICS }\end{array}$ & 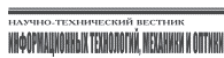 \\
\hline УНИВЕРСИТЕТ ИТМО & November-December 2015 & ISSN 2226-1494 & http://ntv.ifmo.ru/en & \\
\hline
\end{tabular}

\title{
POTENTIALS OF RAMAN BASED SENSOR SYSTEM FOR AN ONLINE ANALYSIS OF HUMAN INHALE AND EXHALE \\ Th. Seeger ${ }^{\mathrm{a}, \mathrm{b}, \mathrm{c}}$, S. Schlüter ${ }^{\mathrm{c}, \mathrm{d}}$, G.N. Lukyanov ${ }^{\mathrm{b}}$
}

${ }^{\text {a }}$ University of Siegen, Siegen, 57076, Germany

b ITMO University, Saint Petersburg, 197101, Russia

${ }^{\mathbf{c}}$ University of Erlangen-Nuremberg, 91052, Erlangen, Germany

${ }^{\mathbf{d}}$ ESYTEC Energie- und Systemtechnik GmbH, Am Weichselgarten 6, 91058, Erlangen, Germany

Corresponding author: thomas.seeger@uni-siegen.de

\section{Article info}

Received 09.10.15, accepted 25.10.15

doi:10.17586/2226-1494-2015-15-6-976-983

Article in English

For citation: Seeger T., Schlüter S., Lukyanov G. Potentials of Raman based sensor system for an online analysis of human inhale and exhale. Scientific and Technical Journal of Information Technologies, Mechanics and Optics, 2015, vol. 16, no. 6, pp. 976-983.

\section{Abstract}

A gas sensor based on spontaneous Raman scattering is proposed for the compositional analysis of single breath events. A description of the sensor as well as of the calibration procedure, which also allows the quantification of condensable gases, is presented. Moreover, a comprehensive characterization of the system is carried out in order to determine the measurement uncertainty. Finally, the sensor is applied to consecutive breath events and allowed measurements with $250 \mathrm{~ms}$ time resolution. The Raman sensor is able to detect all the major gas components, i.e. $\mathrm{N}_{2}, \mathrm{O}_{2}, \mathrm{CO}_{2}$, and $\mathrm{H}_{2} \mathrm{O}$ at ambient pressure with a high temporal resolution. Concentration fluctuations within a single breath event could be resolved.

\section{Keywords}

Raman scattering; multi component gas sensor; low pressure; respiratory studies; multipass cavity; short sampling time; online breath expire air analysis.

Acknowledgements

The authors thank in particular the Erlangen Graduate School in Advanced Optical Technologies (SAOT).

\section{ВОЗМОЖНОСТИ СЕНСОРНОЙ СИСТЕМЫ НА ОСНОВЕ РАМАНОВСКОГО МЕТОДА ДЛЯ ОНЛАЙН-АНАЛИЗА ВДОХА-ВЫДОХА ЧЕЛОВЕКА

$$
\text { Т. Зеегер }{ }^{\mathrm{a}, \mathrm{b}, \mathrm{c}} \text {, С. Шлютер }{ }^{\mathrm{c}, \mathrm{d}} \text {, Г.Н. Лукьянов }
$$

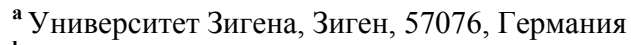

b Университет ИТМО, Санкт-Петербург, 197101, Российская Федерация

c Университет Эрланген-Нюрнберг, Эрланген, 90459, Германия

d ЭСИТЕХ Энерго- и системотехника ООО, Эрланген, 91058, Германия

Адрес для переписки: thomas.seeger@uni-siegen.de

Информация о статье

Поступила в редакцию 09.10 .15 , принята к печати 25.10 .15

doi:10.17586/2226-1494-2015-15-6-976-983

Язык статьи - английский

Ссылка для цитирования: Зеегер Т., Шлютер С., Лукьянов Г.Н. Возможности сенсорной системы на основе рамановского метода для онлайн-анализа вдоха-выдоха человека // Научно-технический вестник информационных технологий, механики и оптики. 2015. T. 15. № 6. С. 976-983.

\section{Аннотация}

Рассмотрен сенсор состава газа на основе спонтанного рамановского рассеяния для анализа состава отдельных вдохов и выдохов. Приведены описания сенсора, а также процедуры калибровки, которая позволяет определить составные части газов в газовой смеси. Кроме того, дается исчерпывающая характеристика системы, которая позволяет определить погрешность измерения. Сенсор применен для измерений при последовательных актах дыхания с разрешением по времени измерений 250 мс. Рамановский сенсор позволяет обнаружить все основные компоненты газа, т.е. $\mathrm{N}_{2}, \mathrm{O}_{2}, \mathrm{CO}_{2}, \mathrm{H}_{2} \mathrm{O}$, при атмосферном давлении с высоким временным разрешением. Сенсор позволяет увидеть колебания концентраций газов в пределах единичного вдоха или выдоха.

\section{Ключевые слова}

рамановское рассеяние; многокомпонентный газовый сенсор; низкое давление; исследования дыхания; многоходовая кювета; короткое время опроса; онлайн-анализ выдыхаемого воздуха.

\section{Благодарности}

Авторы особо благодарят Высшую школу новейших оптических технологий Эрлангена (SAOT). 


\section{Introduction}

Studies of the human respiration have been conducted during the last decades by different specialists who have set different goals. Breath analysis has attracted a considerable attention of scientists and clinicians because the analysis of volatile organic compounds in expired air offers the possibility of certain diseases diagnosis and better understanding of biochemical pathways [1,2]. Such non-invasive medical diagnostic techniques are favorable, especially in combination with optical, laser based techniques that provide a high sensitivity and a good selectivity [3, 4].

Another field of interest is investigation of the so-called respiratory function [5] which will be used to estimate the state of the respiratory tract. There are studies based on the measurements [6-8] and simulation $[9,10]$ of dynamic processes during respiration. In recent years there was a steady tendency to focus these studies on the gas composition of expired air [11-13]. Therefore, it is more and more important to develop new methods and technologies which could open the potential for creation of an online sensor system that would allow precise measurement of the gas composition of the exhaled air. In this case also a fast data acquisition of all gas compound within a time resolution of $200 \mathrm{~ms}$ to $500 \mathrm{~ms}$ is necessary in order to clearly resolve the dynamic behavior of each breath event. This requirement can be met with use of spectroscopic techniques like infrared absorption techniques [14]. Nevertheless a fast analysis of a multicomponent gas mixture by such absorption based techniques requires in most cases a specific detector system for each component.

Spontaneous Raman scattering provides an interesting alternative detection method for identification and determination of all relevant compounds in the breathing gas during consecutive breath events $[15,16]$ In principle, it allows the simultaneous detection of any polyatomic compounds with high temporal resolution using only one sensor system. Due to the high content of information, spontaneous Raman scattering belongs to the mostly developed spectroscopic techniques. In spite of being a challenging technique due to a weak signal, the linear Raman spectroscopy seems to be perfectly suited for the application in gas sensor monitoring [15]. Additionally there is no need for a sample preparation, which enables an access to in situ measurements. The sensor presented in this paper requires no sample preparation and can detect all the main air components such as $\mathrm{O}_{2}, \mathrm{CO}_{2}, \mathrm{~N}_{2}$ and $\mathrm{H}_{2} \mathrm{O}$, at a pressure between $949 \mathrm{hPa}$ and $1004 \mathrm{hPa}$ within a short measurement time. Development of the sensor hardware and especially the signal enhancement by using a multi-pass approach is explained. Also the calibration procedure with use of the $\mathrm{H}_{2} \mathrm{O}$ vapor is described. Finally, its successful application is demonstrated during consecutive human breath events.

\section{Measurement principle}

The well known principles of spontaneous Raman scattering can be found in literature (see e.g. $[17,18]$ ). Therefore only a brief summary is presented here. The spontaneous Raman scattering is a result of an inelastic interaction between light and matter. That means that the scattered radiation frequency is shifted in respect to the incident laser radiation frequency. The respectively red- and blue-shifted signals are defined as the Stokes and anti-Stokes Raman scattering. The observed frequency shift value depends on the energy difference between the virtual energy levels of the involved molecules:

$$
\Delta v_{R}=T^{\prime}\left(v^{\prime}, J^{\prime}\right)-T^{\prime \prime}\left(v^{\prime \prime}, J^{\prime \prime}\right) \text {. }
$$

The parameters marked with one prime are related to the upper energy level and the parameters marked with two primes are related to the lower energy state. The energy term $T(v, J)$ include the values of the vibration and the rotation energies of the molecule, it can be determined in dependence on the vibrational quantum number $v$ and the rotational quantum number $J$. In the simple case of diatomic molecule, for instance $\mathrm{N}_{2}$, the energy term can be expressed by:

$$
\begin{aligned}
T(v, J) & =\omega_{e}\left(v+\frac{1}{2}\right)-\omega_{e} x_{e}\left(v+\frac{1}{2}\right)^{2}+\ldots+\left[B_{e}-\alpha_{e}\left(v+\frac{1}{2}\right)+. .\right] J(J+1) \\
& -\left[D_{e}+\beta_{e}\left(v+\frac{1}{2}\right)+. .\right] J^{2}(J+1)^{2}+\ldots
\end{aligned}
$$

Here, $\omega_{e}, \omega_{e} x_{e}, B_{e}, \alpha_{e}, D_{e}, \beta_{e}$ are the molecule specific constants which can be found in compilation data books, e.g., G. Herzberg [19, 20] for diatomic and polyatomic molecules. One can see from eq. (1) that the energy is influenced only by the molecule specific constants. Consequently, also the Raman shift $\Delta v_{R}$ is a molecule specific parameter that can be used as a fingerprint of this particular molecule. This fingerprint can be used either for the compound identification or for a quantitative analysis of the gas samples while measuring the signal intensity. The detected intensity $I_{i}$ of a vibrational Stokes Raman line of the compound $i$ can be written as

$$
I_{i}=k \Omega \frac{\partial \sigma}{\partial \Omega} n_{i} I_{0},
$$

where $\Omega$ is the collecting solid angle of the optics, $\partial \sigma / \partial \Omega$ is the differential Raman scattering cross section by the compound, $l$ is the length of the measurement volume, and $I_{0}$ is the incident laser intensity. The factor $k$ depends on the experimental setup, and $n_{i}$ is the parameter of interest, i.e. the number density of the specific gaseous 
compound $i$ inside the probe volume. The spectrum of a gas mixture is in principal a superposition of the spectra of the pure substances within the mixture. By evaluating the intensity of the individual Raman spectral bands, the compound concentration can be easily determined. In case of the overlapping bands, a contour fit algorithm can be applied to reconstruct the individual compound signal.

\section{Experimental}

A scheme of the Raman scattering setup is shown in Fig. 1, a. The system includes a Nd: $\mathrm{YVO}_{4} \mathrm{cw}$ laser operating at $\lambda=532 \mathrm{~nm}$ and providing an output power up to $8 \mathrm{~W}$. Due to the relatively low Raman signal intensity, it is difficult to realize short measurement times for the low-pressure gas samples. In order to increase significantly the Raman signal intensities and as a result to achieve the short measurement times, a multipass approach was used. The laser beam is guided into this multipass cavity which focuses the beam into a measurement cell. The volume of this cell was approximately $20 \mathrm{ml}$. In the literature several different possible types of cavities and light traps are described [21-23]. The basic amplification principle in all these types of cavities is always the same. The stimulating laser beam passes through the measurement volume as frequentative as possible. The reflectivity and transmissivity of the individual surfaces at the beam pass exert a huge impact on the single-pass efficiency $\eta$ which is defined as [24]

$$
\eta=\left(\prod_{i=0}^{m-1} R_{i}\right)\left(\prod_{j=0}^{k-1} T_{j}\right),
$$

where the number of reflective surfaces is given by $i$ and the number of translucent components by $j, R_{i}$ describes the reflectivity of the surface $i$, and $T_{j}$ the transmissivity of surface $j$. If all $R_{i}$ and $T_{j}$ have equal values, equation (3) can be simplified to

$$
\eta=R^{m-1} T^{k-1} \text {. }
$$

The signal gain is given by

$$
G_{A}=\frac{1-\eta^{p}}{1-\eta},
$$

where $p$ is the number of passes. The limit for $p \rightarrow \infty$ shows the maximum achievable gain for a given cavity efficiency $\eta$.

$$
\lim _{p \rightarrow \infty} G_{A}=\frac{1}{1-\eta} .
$$
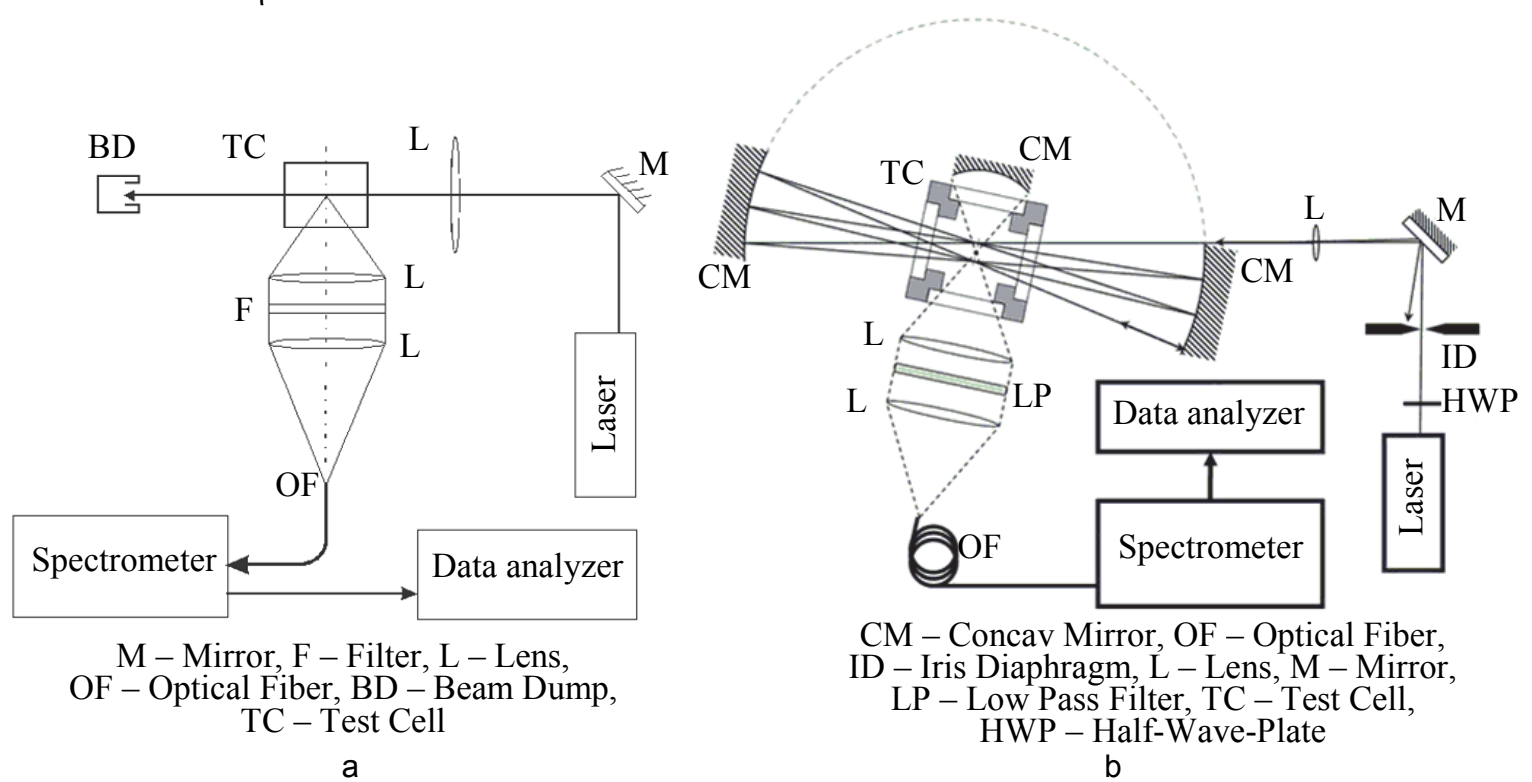

$\mathrm{CM}$ - Concav Mirror, OF - Optical Fiber,

ID - Iris Diaphragm, L - Lens, M - Mirror, LP - Low Pass Filter, TC - Test Cell, HWP - Half-Wave-Plate

b

Fig. 1. Typical Raman setup with perpendicular detection (a); near-confocal cavity (NCC) with two confocal mirrors (b)

In order to achieve the high signal gain starting from a robust $90^{\circ}$-setup a near-confocal cavity (NCC) was used (see Fig. 1, b). In this case 52 beam passes could be realized. The limiting factors were the size of the concave mirrors and the beam acceptance angle of the sample cell. Subsequently the maximal possible gain amplification can be calculated from equation (4) resulting in a theoretical maximum signal gain of $G_{\mathrm{Max}, \mathrm{NCC}}=18.52$. The only problem with using the NCC is that the lasers beam is back-reflected exactly to its origin when the maximum number of passes is realized. In the experiment, the cavity adjustment was slightly misaligned so that the outgoing beam was deflected a little in order to avoid the beam entering back into laser 
source. The Raman scattered light is collected perpendicularly to the incident laser beam using a telescope optics with a large solid angle on the collecting side and an optical filter to suppress undesirable stray light and the Rayleigh line. Additionally the light which is scattered at an angle of $270^{\circ}$ is redirected in the collecting optics. The signal is then directed into optical fiber and guided into a spectrometer with a back-thinned CCD sensor. Thermal noise is minimized by thermal conditioning of the CCD chip. The detectable spectral range was adjusted according to the Raman shifts by the gases under investigation.

The data evaluation method used in this work is based on the contour-fit procedure, the component relative concentration in vol. \% being determined all-around automatically. The intensity of the Raman bands is linear depending on the number density of the molecules $n$, see equation (2). The measured signal intensity dependence on the Raman shift is expressed by a finite vector $\vec{S}_{M}$. The contour-fit procedure, based on the Levenberg-Marquardt algorithm, compares the measured signal $\vec{S}_{M}$ with a synthetic spectrum $\vec{S}_{F i t}$ consisting of the spectra of the pure substances $\vec{S}_{e}$. This procedure can be formulated as an optimization problem:

$$
\min \left(\frac{1}{q} \sum_{x=0}^{q-1}\left(S_{F i t}(x)-S_{M}(x)\right)^{2}\right),
$$

where $S_{F i t}(x)$ is one data point of the $q$ spectrum values respecting the spectral position, and $S_{M}(x)$ is one data point of the measured spectrum with the same number of elements.

The goal of the optimization problem is to find the synthesized spectrum $\vec{S}_{F i t}$ that has the smallest deviation from the measured spectrum $\vec{S}_{M}$. The setup specific scattering cross-sections for the individual substances are determined by a calibration process. At the first step, the spectra of all pure substances are recorded and normalized. Secondly, a Raman spectrum of the gas mixture containing all relevant compounds with known concentration is recorded. To take setup specific influences into account these measurements are done with the same sensor system used in the gas analysis process. As far as the mixtures containing the water vapors are not stable due to condensation, they are not commercially available. Therefore, it was necessary to create the calibration mixtures under temperature and pressure controlled conditions shortly before calibration. For these calibration measurements the Raman sensor is additionally equipped with a gas circulator to ensure an adequate mixing of the different compounds. The measurement cell is equipped with a high precision pressure transducer and with electrically controlled heating system and K-type thermocouple. The precision and accuracy of the Raman system was tested by means of the monitoring and evaluating 500 single shot Raman spectra taken in room air and synthetic air at $981 \mathrm{hPa}$ and $294 \mathrm{~K}$. The time resolution was $250 \mathrm{~ms}$. The $\mathrm{H}_{2} \mathrm{O}$ concentration distribution measured in room air is shown In Fig. 2, a. A mean $\mathrm{H}_{2} \mathrm{O}$ concentration of 1.03 vol.\% and a standard deviation of $0.15 \%$ have been achieved. Corresponding hygrometer measurements show a $\mathrm{H}_{2} \mathrm{O}$ concentration of 1.16 vol.\%. The synthetic air consists of $79.5 \mathrm{vol} . \% \mathrm{~N}_{2}$ and $20.5 \mathrm{vol} . \% \mathrm{O}_{2}$. The corresponding Raman concentration distributions were shown in Fig. 2, b, c, together with the mean values and the standard deviations.

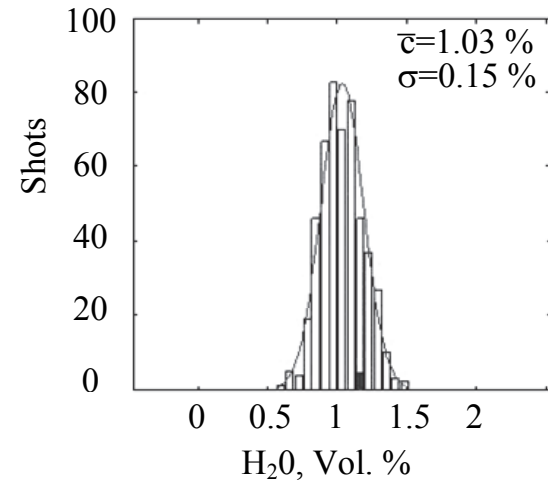

a

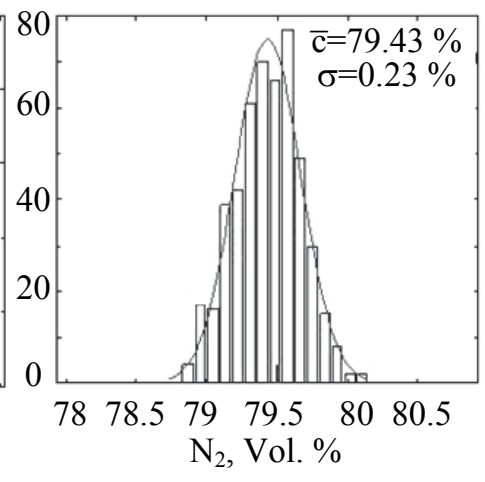

$\mathrm{b}$

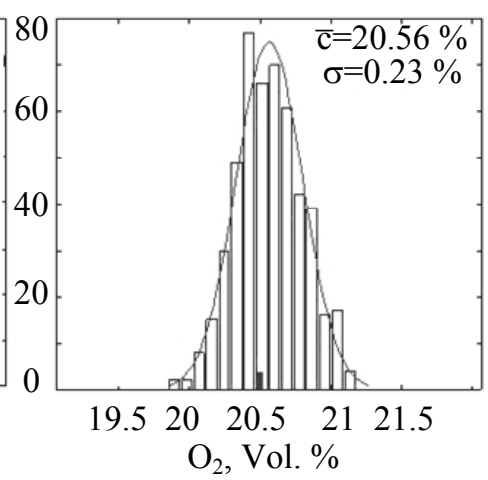

$\mathrm{c}$

Fig. 2. Histogram of 500 single shot Raman measurements taken in gas mixtures with known composition. $\mathrm{H}_{2} \mathrm{O}$ content in room air (a); $\mathrm{N}_{2}$ concentration of synthetic air (b); $\mathrm{O}_{2}$ concentration of synthetic air (c). The reference values are indicated with a red bars in each graph

\section{Experimental Results}

In order to analyze human breath events an experimental setup as shown in Fig. 3 was used. With this setup it was possible to achieve inspiratory and expiratory breath events with a time resolution of $250 \mathrm{~ms}$. Taking into consideration a significant dependence of the Raman spectra on temperature and pressure, the setup was equipped with the pressure indicator and thermocouple of $\mathrm{K}$ type. In the experiments presented in this study the temperature variation was kept within $\pm 5 \mathrm{~K}$ and a pressure variation occurs only in a range of $\pm 25 \mathrm{hPa}$ (compare with given in [25] $10 \mathrm{~K}$ and $1 \mathrm{MPa}$, respectively). 


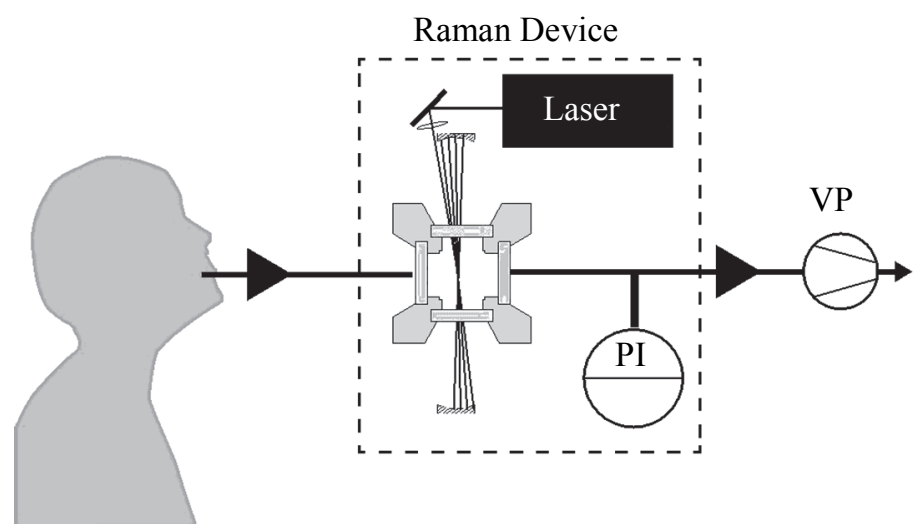

Fig. 3. Raman spectroscopy setup used for analysis of human breath events (PI - pressure indicator; TC - thermocouple; VP - vacuum pump)

A typical Raman spectrum of the single human breath event during inspiration is shown in Fig. 4, a, together with the best fitting synthesized spectrum. The individual vibrational Raman transitions in molecules $\mathrm{O}_{2}, \mathrm{~N}_{2}, \mathrm{CO}_{2}$ and $\mathrm{H}_{2} \mathrm{O}$ can be seen clearly. Difference between the experimental spectrum and the synthesized spectrum is shown Fig. 4, b. A concentration of 75.69 vol.\% $\mathrm{N}_{2}, 19.99$ vol. $\% \mathrm{O}_{2}$ and 4.42 vol.\% $\mathrm{H}_{2} \mathrm{O}$ was evaluated. As for $\mathrm{CO}_{2}$, a concentration of 0.1 vol.\% was evaluated, that value lies (according to Fig. 2) within the uncertainty of measurements and it is probably caused by the noise. The corresponding expiratory case (including here a significant amount of $\mathrm{CO}_{2}$ also) is displayed in Figs. 4, c, d. The measured component concentrations were 76.26 vol. $\% \mathrm{~N}_{2}, 14.61$ vol. $\% \mathrm{O}_{2}, 4.47$ vol. $\% \mathrm{H}_{2} \mathrm{O}$ and 4.41 vol. $\% \mathrm{CO}_{2}$.

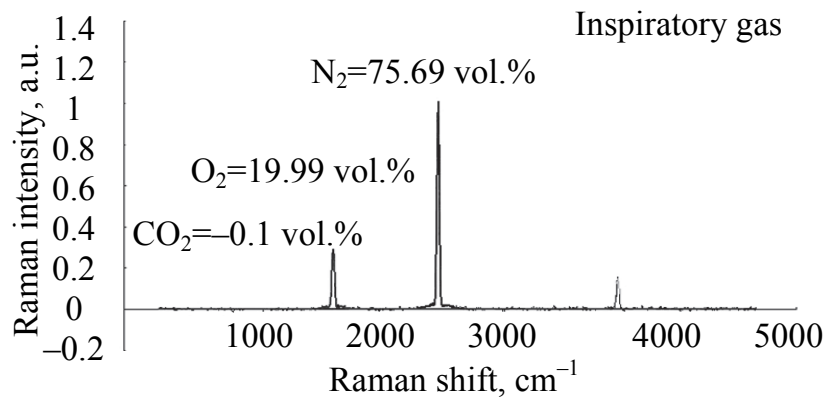

a

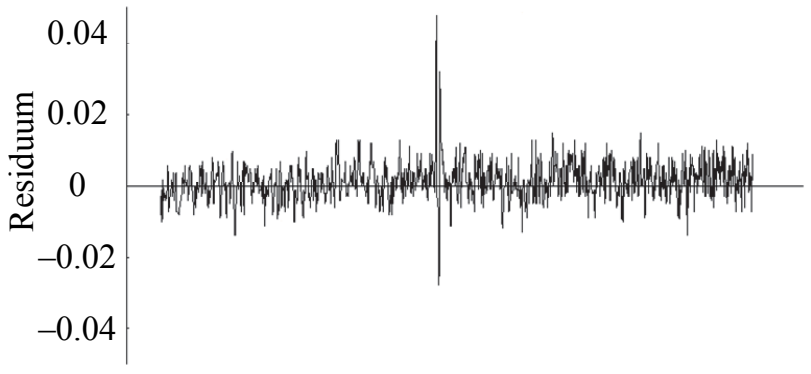

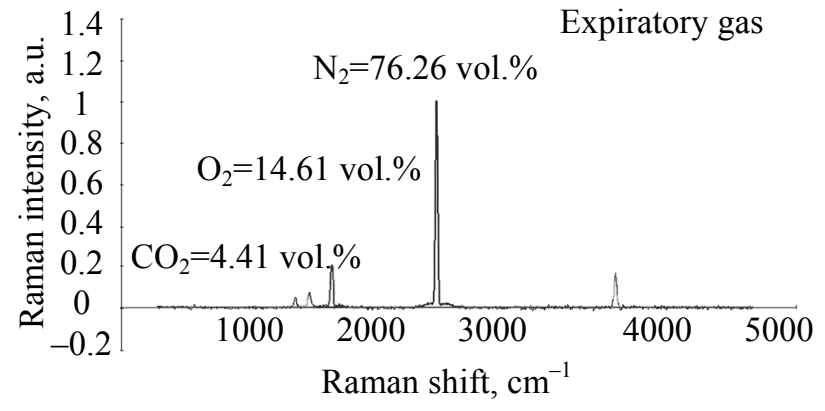

C

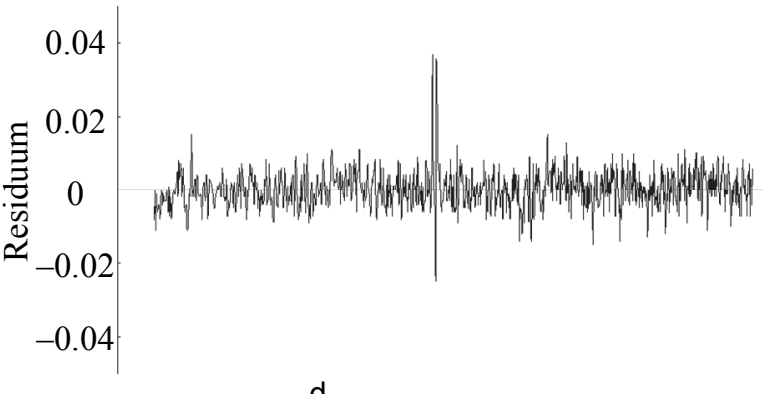

Fig. 4. Normalized Raman spectrum taken during a human inspiration event together with best fitting synthesized spectrum (a); Residual spectrum of the spectra in Fig. 4, a (b); Normalized Raman spectrum of a respiratory human breath event together with best fitting synthesized spectrum (c); Residual spectrum of the spectra in Fig. 4, c (d)

In Fig. 5, a, measurement series for three consecutive breath events is presented. The measurements were done with the setup shown in Fig. 3. The vacuum pump in Fig. 3 has an adjustable flow rate, being set to a constant value in order to ensure a sufficient sample renewal within the test cell. At starting the measurement series, the typical room air was analyzed with concentrations of the components as follows: $\mathrm{N}_{2}=78.5 \mathrm{vol} . \%, \mathrm{O}_{2}$ $=20.7$ vol. $\% \mathrm{CO}_{2}=0.1 \mathrm{vol} . \%$, and $\mathrm{H}_{2} \mathrm{O}=0.69 \mathrm{vol} . \%$. After $17 \mathrm{~s}$ a pressure drop down to $965 \mathrm{hPa}$ was observed caused by starting of the inspiration cycle. The component concentration was kept constant until the expiratory gas enters the measurement cell. After $26 \mathrm{~s}$ since starting the measurements, the pressure is increased up to $0.995 \mathrm{hPa}$ caused by starting of the expiration cycle. With a time delay of 2 seconds the expiratory gas entered into the measurement cell and the concentration changes could be observed. Since the expiratory air has a high 
water vapor content $\left(\mathrm{H}_{2} \mathrm{O}=3.31 \mathrm{vol} . \%\right)$, the component concentrations was changed giving the following values: 77.92 vol.\% for $\mathrm{N}_{2}, 13.60$ vol.\% for $\mathrm{O}_{2}$ and 5.18 vol.\% for $\mathrm{CO}_{2}$. All expiratory events show small concentration fluctuations. These fluctuations can be clearly resolved by the Raman sensor. In order to show that in more detail, two single shot spectra taken during the third expiratory event between $72 \mathrm{~s}$ and $83 \mathrm{~s}$ are compared in Fig. 6. The corresponding measurement moments are marked with black points and red dots in Fig. 5. These $\mathrm{CO}_{2}$ Raman spectra are displayed in Fig. 6 and differences are clearly noticeable. The corresponding $\mathrm{CO}_{2}$ concentrations are 4.3 vol. $\%$ and 5.12 vol. $\%$.

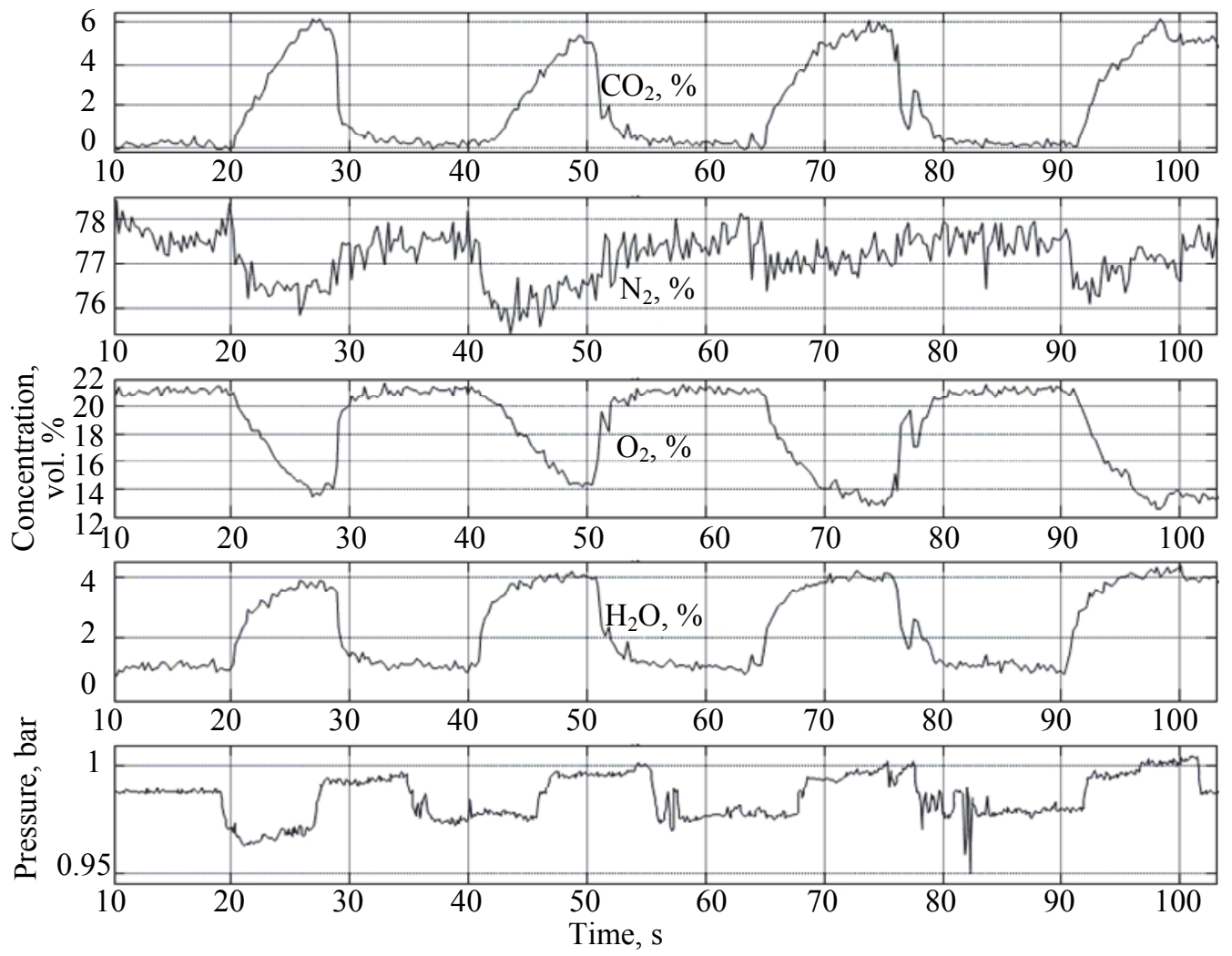

Fig. 5. Measurement series showing the component concentration and the pressure variation during three consecutive breath events. The $\mathrm{CO}_{2}$ spectra in two indicated measurement points (they are shown between $70 \mathrm{~s}$ and $75 \mathrm{~s}$ on the $\mathrm{CO}_{2}$ plot) are displayed below in Fig. 6.

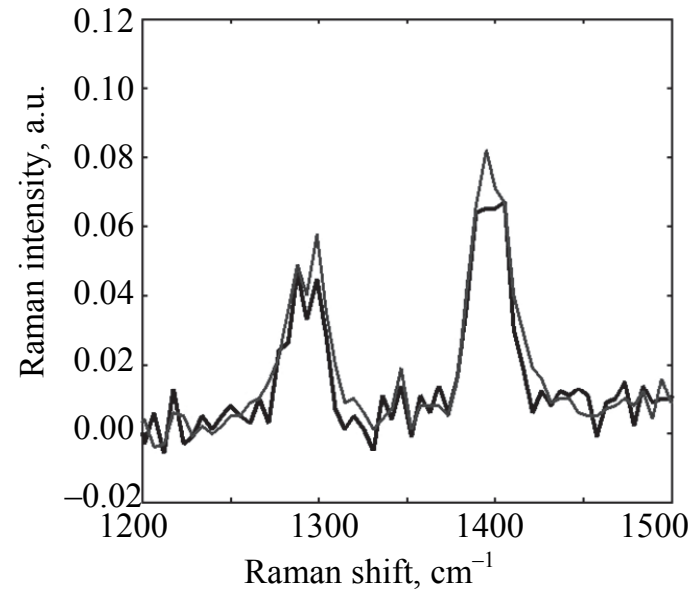

Fig. 6. The $\mathrm{CO}_{2}$ single shot Raman spectra recorded during the measurement in the points marked in Fig. 5 .

However, the concentration fluctuations for $\mathrm{N}_{2}$ (see Fig. 5) quite fit in well studied dependence of the solubility of nitrogen in the blood depending on the air pressure and can manifest itself as decompression sickness.

\section{Summary}

The presented Raman spectrum method is capable to identify and quantify all major air components of interest during a single breath event with a time resolution of $250 \mathrm{~ms}$. The absolute pressure is typically between 
950 and $1000 \mathrm{hPa}$. The Raman spectrum method is able to measure the gas components concentration online without any sample preparation. In order to increase the Raman signal and to enable short measurement times of $250 \mathrm{~ms}$, the sensor is equipped with the near-confocal cavity. The applicability of this Raman system for analysis of the single breath events was demonstrated. All components of interest were measured and clearly resolved online with small concentration fluctuations of 0.82 vol. \% or less. The results obtained demonstrate the potential of presented Raman sensor for the future respiratory function investigations.

\section{References}

1. Buszewski B., Kesy M., Ligor T., Amann A. Human exhaled air analytics: biomarkers of diseases // Biomedical Chromatography. 2007. V. 21. N 6. P. 553-566. doi: 10.1002/bmc.835

2. Miekisch W., Schubert J.K., Noeldge-Schomburg G.F.E. Diagnostic potential of breath analysis - focus on volatile organic compounds // Clinica Chimica Acta. 2004. V. 347. N 1-2. P. 25-39. doi: 10.1016/j.ccen.2004.04.023

3. Bögözi T., Popp J., Frosh T. Fiber-enhanced Raman multi-gas spectroscopy: what is the potential of its application to breath analysis? // Bioanalysis. 2015. V. 7. N 3. P. 281-284. doi: 10.4155/BIO.14.299

4. Wojtas J., Bielecki Z., Stacewicz T., Mikołajczyk J., Nowakowski M. Ultrasensitive laser spectroscopy for breath analysis // Opto-Electronics Review. 2001. V. 20. N 1. P. 26-39. doi: 10.2478/s11772-012-0011-4

5. Krotov A. Modern methodological approaches in the evaluation of nasal breathing function // Vestnik Otorinolaringologii. 1998. N 4. P. 51-52. (In Russian)

6. Voronin A.A., Luk'yanov G.N., Neronov R.V. Computational modeling of airflow in nonregular shaped channels // Scientific and Technical Journal of Information Technologies, Mechanics and Optics. 2013. N 3(85). P. 113-118.

7. Luk'yanov G.N., Polishuk S.A. Nonlinear dynamical modeling for interaction processes of human breathing and tachycardia on the basis of given measurements // Scientific and Technical Journal of Information Technologies, Mechanics and Optics. 2013. N 4(86). P. 67-72.

8. Mutlu G.M., Garey K.W, Robbins R.A., Danziger L.H., Rubinstein I. Collection and analysis of exhaled breath condensate in humans // American Journal of Respiratory and Critical Care Medicine. 2001. V. 164. N 5. P. 731-737. doi: 10.1164/ajrccm.164.5.2101032

9. Voronin A.A., Luk'yanov G.N., Frolov E.V. Detached-eddy simulation of turbulent airflow // Scientific and Technical Journal of Information Technologies, Mechanics and Optics. 2014. N 1(89). P. 187-192.

10. Kistenev Y.V., Akbasheva O.E., Kutshma O.S., Dyukova E.V., Stepanova E.A., Pavlov V.S., Gulaja V.S. The gas composition of exhaled air and biochemical indicators of sputum in chronic obstructive pulmonary disease // Health \& Education Millennium. 2012. V. 14. N 2. P. 68.

11. Yanov, Y., Shcherbakova N., Nacharov P. An analysis of the gas composition of exhaled air in the diagnosis of diseases // Russian Otorhinolaryngology. 2005. N 4. P. 126-132.

12. Herbig J., Müller M., Schallhart S., Titzmann T., Graus M., Hansel A. On-line breath analysis with PTR-TOF // Journal of Breath Research. 2009. V. 3. N 2. Art. 027004. doi: 10.1088/1752-7155/3/2/027004

13. Schulze-König T., Wacker L., Synal H.-A. Direct radiocarbon analysis of exhaled air // Journal of Analytical Atomic Spectrometry. 2011. V. 26. N 2. P. 287-292. doi: 10.1039/C0JA00039F

14. Portner P.M., LaForge D.H. Method and Apparatus for Pulmonary Function Analysis. Patent US4083367, 1978.

15. Schlüter S., Popovska-Leipertz N., Seeger T., Leipertz A. Gas sensor for volatile anesthetic agents based on Raman scattering // Physics Procedia. 2012. V. 39. P. 835-842. doi: 10.1016/j.phpro.2012.10.108

16. Schlüter S., Asbach S., Popovska-Leipertz N., Seeger T., Leipertz A. A signal enhanced portable Raman probe for anesthetic gas monitoring // Scientific and Technical Journal of Information Technologies, Mechanics and Optics. 2015. V. 15. N 2. P. 215-226. doi: 10.17586/2226-1494-2015-15-2-218-226

17. Schrader B., Bougeard D. Infrared and Raman Spectroscopy. Methods and Applications. NY: Wiley-VCH, Weinheim, 1995. $787 \mathrm{p}$.

18. Tobin M. C. Laser Raman Spectroscopy. NY: Wiley-Interscience, 1971.

19. Herzberg G. Molecular Spectra and Molecular Structure. I. Spectra of diatomic molecules. $2^{\text {nd }}$ ed. D. van Nostrand Company Inc., 1966. 672 p.

20. Herzberg G. Molecular Spectra and Molecular Structure. II. Infrared and Raman spectra of polyatomic molecules. 2nd ed. D. van Nostrand Company Inc., 1966. 644 p.

21. Hill R.A., Mulac A.J., Hackett C.E. Retroreflecting multipass cell for Raman scattering // Applied Optics. 1977. V. 16. N 7. P. 2004-2006. doi: 10.1364/AO.16.002004

22. Hill R.A., Hartley D.L. Focused, multiple-pass cell for Raman scattering // Applied Optics. 1974. V. 13. N 1. P. 186-192. doi: 10.1364/AO.13.000186

23. Santavicca D.A. A high energy, long pulse Nd: Yag laser multipass cell for Raman scattering diagnostics // Optics Communication. 1979. V. 30. N 3. P. 423-425. doi: 10.1016/0030-4018(79)90385-7

24. Waldherr G.A., Lin H. Gain analysis of an optical multipass cell for spectroscopic measurements in luminous environments // Applied Optics. 2008. V. 47. N 7. P. 901-907. doi: 10.1364/AO.47.000901 
25. Eichmann S.C., Weschta M., Kiefer J., Seeger T., Leipertz A. Characterization of a fast gas analyzer based on Raman scattering for the analysis of synthesis gas // Review of Scientific Instruments. 2010. V. 81. N 12. Art. 125104. doi: 10.1063/1.3521397

Thomas Seeger

Sebastian Schlueter

Gennadiy N. Lukyanov

Зеегер Томас

Шлютер Себастиан

Лукьянов Геннадий Николаевич
Prof. Dr.-Ing., Professor, Head of Department, Universitaet Siegen, Siegen, 57076, Germany; Professor, ITMO University, Saint Petersburg, 197101, Russian Federation; Professor, Mentor, Friedrich-Alexander Universitaet Erlangen-Nuernberg, Erlangen, 90459, Germany, thomas.seeger@uni-siegen.de

researcher, Friedrich-Alexander Universitaet Erlangen-Nuernberg, Erlangen, 90459, Germany; research worker, ESYTEC Energie- und Systemtechnik GmbH, Erlangen, 91058, Germany, sebastian.schlueter@uni-siegen.de

D.Sc., Professor, Head of Chair, ITMO University, Saint Petersburg, 197101, Russian Federation, gen-lukjanow@yandex.ru

доктор технических наук, профессор, руководитель института, Университет Зигена, Зиген, 57076, Германия; профессор, Университет ИТМО, Санкт-Петербург, 197101, Российская Федерация; профессор, руководитель, Университет ЭрлангенНюрнберг, Эрланген, 90459, Германия, thomas.seeger@uni-siegen.de научный сотрудник, Университет Эрланген-Нюрнберг, Эрланген, 90459, Германия; сотрудник, ЭСИТЕХ Энерго- и системотехника ООО, Эрланген, 91058, Германия, sebastian.schlueter@uni-siegen.de доктор технических наук, профессор, заведующий кафедрой, Унивеситет ИТМО, Санкт-Петербург, gen-lukjanow@yandex.ru 